\title{
Sediment geochemistry and accumulation rates on the northeastern shelf of the Gulf of Cádiz (SW Iberian Peninsula)
}

\author{
ROBERTA GUERRA ${ }^{1,2}$, ENRICO DINELLI ${ }^{1,3}$, SERENA RIGHI ${ }^{1,2}$, JESÚS M. FORJA $^{4}$ \\ and ENRIQUE GARCÍA-LUQUE ${ }^{4}$ \\ ${ }^{1}$ Centro Interdipartimentale di Ricerca per le Scienze Ambientali (C.I.R.S.A.), University of Bologna, Via S.Alberto 163, \\ Ravenna 48100, Italy. E-mail: roberta.guerra@unibo.it \\ ${ }^{2}$ Department of Physics, University of Bologna, Viale B. Pichat 6/2, Bologna 40126, Italy. \\ ${ }^{3}$ Department of Earth and Geological-Environmental Sciences, University of Bologna, Piazza Porta San Donato 1, \\ Bologna 40127, Italy. \\ ${ }^{4}$ Departamento de Química Física, Facultad Ciencias del Mar y Ambientales (CASEM), Polígono Río San Pedro s/n, \\ 11510 Puerto Real, Cádiz, Spain.
}

\begin{abstract}
SUMMARY: Geochemistry, total organic carbon and total nitrogen of three sediment cores collected in the Gulf of Cádiz and the Guadalquivir prodelta areas in Spain were investigated. The C/N ratio, mostly around 10, seems to indicate a predominantly marine origin for the sedimentary organic matter. Major and minor elements $(\mathrm{Si}, \mathrm{Ti}, \mathrm{Al}, \mathrm{Fe}, \mathrm{Mg}, \mathrm{Ca}, \mathrm{K}, \mathrm{Na}, \mathrm{P}, \mathrm{S})$ and trace elements (Mn, Sc, V, Cr, Ni, Cu, Zn, Rb, Sr, Y, Zr, Ba, Ce, Pb, Hg) showed significant differences in bulk chemical composition between the two areas. Despite the effects of bioturbation, vertical changes in downcore profiles of heavy metals occur only in the cores of the Cádiz area, although the concentrations keep to low levels. The relatively high concentrations of $\mathrm{Zr}$ and $\mathrm{Y}$, elements commonly associated with the heavy minerals fraction, at the top of cores from the Cádiz area are attributed to an enrichment of heavy minerals related to selective transport that concentrates this fraction. ${ }^{137} \mathrm{Cs}$ and ${ }^{210} \mathrm{~Pb}$ activities in one of the two sediment cores collected in the Gulf of Cádiz were also measured. The distribution of excess ${ }^{210} \mathrm{~Pb}$ was used to determine the modern (last $100 \mathrm{yr}$ ) mass accumulation rate and the depth of sediment mixing on the continental shelf of the gulf. Estimated sediment accumulation rate was $0.1 \mathrm{~g} \mathrm{~cm}^{-2} \mathrm{yr}^{-1}$. The uppermost $4 \mathrm{~cm}$ had uniform excess ${ }^{210} \mathrm{~Pb}$ activity profiles above a region of steadily decreasing ${ }^{210} \mathrm{~Pb}$ activity, and this phenomenon was attributed to sediment mixing (bioturbation). ${ }^{137} \mathrm{Cs}$ activity was lower than $3 \mathrm{~Bq} \mathrm{~kg}^{-1}$ and the profile does not show evidence of fallout peaks.
\end{abstract}

Keywords: radioactive tracers, ${ }^{210} \mathrm{~Pb},{ }^{137} \mathrm{Cs}, \gamma$-spectrometry, mass accumulation rates, bioturbation, geochemistry, Gulf of Cádiz.

RESUMEN: GEOQUímiCa SEDIMENTARIA Y TASAS DE ACUMULACIÓN EN LA PLATAFORMA NORORIENTAL DEL GOLFO DE CÁDIZ (SO DE LA PENÍNSUla IBÉRICA). - Se ha estudiado la geoquímica, el carbono orgánico total y el nitrógeno total de tres testigos de sedimento tomados en el área del Golfo de Cádiz así como en el área del prodelta del río Guadalquivir (España). $\mathrm{El}$ cociente $\mathrm{C} / \mathrm{N}$, con un valor alrededor de 10 , parece indicar un origen predominantemente marino para la materia orgánica sedimentaria. Elementos mayoritarios y minoritarios ( $\mathrm{Si}, \mathrm{Ti}, \mathrm{Al}, \mathrm{Fe}, \mathrm{Mg}, \mathrm{Ca}, \mathrm{K}, \mathrm{Na}, \mathrm{P}, \mathrm{S}$ ) y oligoelementos (Mn, Sc, V, Cr, $\mathrm{Ni}, \mathrm{Cu}, \mathrm{Zn}, \mathrm{Rb}, \mathrm{Sr}, \mathrm{Y}, \mathrm{Zr}, \mathrm{Ba}, \mathrm{Ce}, \mathrm{Pb}, \mathrm{Hg}$ ) muestran diferencias significativas en el grueso de la composición química entre las dos áreas. A pesar de los efectos de la bioturbación, sólo aparecen cambios verticales en los perfiles de metales traza de los testigos del área de Cádiz, si bien las concentraciones se mantuvieron en niveles bajos. Las concentraciones relativamente altas de $\mathrm{Zr}$ y Y, elementos generalmente asociados a fracciones de minerales pesados, en la parte superior de los testigos del área de Cádiz se atribuyen a un enriquecimiento de minerales pesados relacionado con el transporte selectivo que ayuda a concentrar esta fracción. También se han medido las actividades de ${ }^{137} \mathrm{Cs}$ y ${ }^{210} \mathrm{~Pb}$ en uno de los dos testigos de sedimento tomados en el Golfo de Cádiz. Se ha empleado la distribución de exceso de ${ }^{210} \mathrm{~Pb}$ para determinar la tasa reciente de acumulación de masa (para los últimos 100 años), así como la profundidad de mezcla de sedimentos en la plataforma continental del golfo. La tasa de acumulación de sedimentos estimada fue de $0.1 \mathrm{~g} \mathrm{~cm}^{-2} \mathrm{yr}^{-1}$. Los $4 \mathrm{~cm}$ superiores mostraron unos perfiles de exceso de actividad de ${ }^{210} \mathrm{~Pb}$ uniformes, por encima de una región de firme actividad decreciente en actividad de ${ }^{210} \mathrm{~Pb}$ y este fenómeno se atribuyó a mezcla del sedimento (bioturbación). La actividad de ${ }^{137} \mathrm{Cs}$ fue inferior a $3 \mathrm{~Bq} \mathrm{~kg}^{-1}$ sin presentar los perfiles evidencias de picos debidos a lluvia radiactiva.

Palabras clave: trazadores radiactivos, ${ }^{210} \mathrm{~Pb},{ }^{137} \mathrm{Cs}, \gamma$-espectrometría, tasas de acumulación de masa, bioturbación, geoquímica, golfo de Cádiz. 


\section{INTRODUCTION}

The importance of the Gulf of Cadiz continental margin (SW Spain) lies in its proximity to the Strait of Gibraltar, a point of singular geographic interest because it is the place where the Atlantic Ocean and the Mediterranean Sea interchange their water masses (Gutiérrez-Mas et al., 2003). The configuration of the study area in this study is the result of a natural evolution determined by geological agents, principally the littoral dynamics, the mouth of the river Guadalquivir and the aeolian regime of the zone (Ligero et al., 2005). Continental shelves (defined as $30-200 \mathrm{~m}$ areas) represent $<10 \%$ of the global oceanic area (Berelson et al., 2003) and are considered as the transition zone between the continents and the open ocean. They receive large amounts of terrestrial organic matter and nutrients, mainly through river systems. Because the mean water depth of continental shelves is significantly less than in the open ocean, the seafloor sediments play a significantly more important role in the biogeochemistry and ecology of these systems (MacKenzie et al., 2005).

Other major topics that geochemical studies can face in these areas are those of sediment provenance, which is useful to define sediment sources and their dispersion patterns, and to assess local human impacts (Carranza-Edwards et al., 2005; Spagnoli et al., 2008).

Natural and artificial radionuclides such as ${ }^{210} \mathrm{~Pb}$ and ${ }^{137} \mathrm{Cs}$ can provide useful information as tracers to determine time scales for various sedimentary processes affecting continental shelves (Sánchez-Cabeza et al., 1999; Palinkas and Nittrouer, 2007; Jouanneau et al., 2008). ${ }^{210} \mathrm{~Pb}$ (half life: 22.3 years) is a naturally occurring radionuclide belonging to the ${ }^{238} \mathrm{U}$ series whereas ${ }^{137} \mathrm{Cs}$ (half life: 30.2 years) is produced artificially as a result of anthropogenic activities.

Two cruises were carried out in two periods of the year 2006 on the northeastern shelf of the Gulf of Cádiz. This paper presents the results obtained from the study of sediment cores that were sampled on these cruises in order to characterize in this area the geochemistry of sediments and the accumulation rates by means of ${ }^{210} \mathrm{~Pb}$ and ${ }^{137} \mathrm{Cs}$ radioisotopes.

\section{MATERIALS AND METHODS}

\section{Study site}

The study was carried out on the northeastern shelf of the Gulf of Cádiz (southwestern coast of the Iberian Peninsula; Fig. 1). The Gulf of Cádiz is the meeting place for the North Atlantic Ocean and the Mediterranean Sea through the Strait of Gibraltar. This gulf is a wide basin influenced by: a) the dense plume of Mediterranean water that penetrates through the strait, and b) the freshwater inputs from several adjacent rivers, such as the Guadiana, the Guadalquivir, the Tinto and the Odiel.

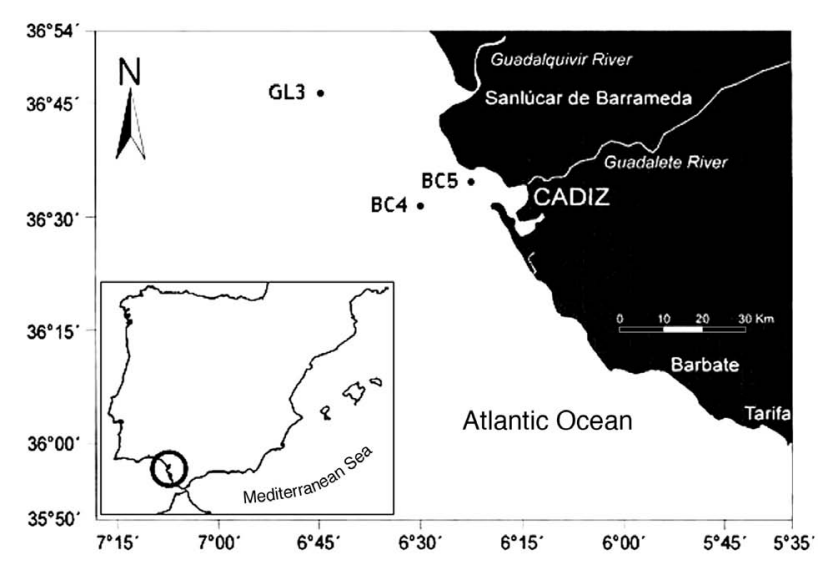

FIG. 1. - Location of the study area and sampling area on the northern shelf of the Gulf of Cádiz (SW Spain). Sediment cores BC4 and BC5 were obtained from the outer Bay of Cádiz, whereas core GL3 was obtained from the submarine prodelta of the River Guadalquivir.

The River Guadalquivir is the main fluvial source draining into the Gulf of Cádiz margin, with a mean annual water discharge of $160 \mathrm{~m}^{3} \mathrm{~s}^{-1}$ (Van Geen et al., 1997). The circulation on the northeastern shelf of the Gulf of Cádiz is mainly controlled by: a) North Atlantic Surface Water (NASW), which flows towards the east and southeast to the Strait of Gibraltar, and b) an intermittent counter-current system which seems to be considerably induced by wind forcing (Lobo et al., 2004). The Cádiz area has a regime of semidiurnal tides and is characterized by predominant winds from the west and the east.

The data reported in this paper belong to two cruises on board the R/V Mytilus covering two seasonal periods: June 2006 and November 2006 (summer and autumn, respectively). Three sampling stations were selected for the study, and sediment cores were sampled by scuba divers. Two stations were located in the Bay of Cádiz and its neighbouring outer region (BC4 and BC5) and the other one off the mouth of the River Guadalquivir (GL3) (Fig. 1). Station GL3 is located on the Guadalquivir submarine prodelta, which is characterized by high fluvial supply and a moderate hydrodynamic regime (Lobo et al., 2004), whereas the BC stations are located in a more energetic area affected by the tidal currents between the Bay of Cádiz and the outer shelf. Sediments in the study area are mainly siliciclastic, with $25 \%$ of bioclastic carbonates, predominantly calcite (Gutiérrez-Mas et al., 2003).

Specifically, in this research work three cores were analyzed: GL3 (from station GL3), which was extracted in June 2006, and BC4 and BC5 (from stations BC4 and BC5), which were extracted in June 2006 and November 2006, respectively.

Cores were extracted without alteration to the structure of the sediment. In order to ensure the immobilization of the core, the pipes were cooled at $-10^{\circ} \mathrm{C}$. Afterwards, the sediment profiles were cut into $1-\mathrm{cm}$ thick slices up to a depth of 14-15 cm for GL3, 9-10 $\mathrm{cm}$ for BC4 and 13-14 $\mathrm{cm}$ for BC5. 


\section{Organic carbon and total nitrogen analysis}

Sediment samples were ground to a fine powder with an agate pestle and mortar. Total carbon (TC) and nitrogen (TN) contents were determined using elemental analysis of combusted aliquots $(30 \mathrm{mg})$ with a TCM 480 Carlo Erba Elemental Analyzer. Total organic carbon (TOC) was measured on decarbonated samples $(1.5 \mathrm{~N} \mathrm{HCl})$ following the method of Hedges and Stern (1984). The precision of this method based on replicate measurements $(n=30)$ of a standard reference sediments BCSS- 1 is $2.0 \%$ for TOC and $1.2 \%$ for TN.

\section{Sediment geochemistry}

Bulk chemical composition for major and minor elements ( $\mathrm{Si}, \mathrm{Ti}, \mathrm{Al}, \mathrm{Fe}, \mathrm{Mg}, \mathrm{Ca}, \mathrm{K}, \mathrm{Na}, \mathrm{P}, \mathrm{S})$ and trace elements $(\mathrm{Mn}, \mathrm{Sc}, \mathrm{V}, \mathrm{Cr}, \mathrm{Ni}, \mathrm{Cu}, \mathrm{Zn}, \mathrm{Rb}$, $\mathrm{Sr}, \mathrm{Y}, \mathrm{Zr}, \mathrm{Ba}, \mathrm{Ce}, \mathrm{Pb}$ ) were determined by $\mathrm{X}$-ray fluorescence spectrometry using a Philips PW 1480 spectrometer equipped with an $\mathrm{Rh}$ tube on pressed powder pellets following the matrix correction methods of Franzini et al. (1972) and Leoni et al. (1982). About 30 international reference materials were used for the calibration, and PACS-2 (marine sediment, National Research Council, Canada), NBS1646a (estuarine sediment, National Institute of Standards and Technology, USA) as external monitors. Precision and accuracy were better than $5 \%$ for trace-element determinations.

Total mercury was determined by cold vapour atomic absorption spectrometry (CVAAS) after hot digestion of $0.5-1 \mathrm{~g}$ dry sediment with concentrated $\mathrm{HNO}_{3}+\mathrm{H}_{2} \mathrm{SO}_{4}$ for $3 \mathrm{~h}$ at $90^{\circ} \mathrm{C}$ (Fabbri et al., 2001). The analytical precision of the $\mathrm{Hg}$ data, estimated as relative percent difference among replicates, was $5.0 \%(\mathrm{n}=10)$, and analytical accuracy estimated as the mean\% recovery in PACS-2 reference sediment $(\mathrm{Na}-$ tional Research Council, Canada) was 95\% ( $\mathrm{n}=10)$.

\section{Radioactive tracer analyses}

Water content and wet and dry bulk densities were calculated from samples that were weighed before and after drying at $60^{\circ} \mathrm{C}$ until constant weight. Dry homogenized samples were packed in $9.5-\mathrm{mL}$ sealed Petri dishes and 'aged' at least four weeks to allow the equilibrium between ${ }^{222} \mathrm{Rn}$ and its descendants, ${ }^{214} \mathrm{Bi}$ and ${ }^{214} \mathrm{~Pb}$, to be established for the determination of ${ }^{226} \mathrm{Ra}$. Radioactive tracers $\left({ }^{210} \mathrm{~Pb}\right.$, ${ }^{226} \mathrm{Ra}$, and ${ }^{137} \mathrm{Cs}$ ) were measured on sediment core BC4 using HPGe coaxial detector with an energy resolution (full-width at half-maximum) of $1.9 \mathrm{keV}$ at $1.33 \mathrm{MeV}\left({ }^{60} \mathrm{Co}\right)$, and a $22.6 \%$ efficiency. Efficiency calibration was performed using a Standard U-Th Ore (Canada Centre for Mineral and Energy Technology). Reference sediments IAEA 315 and IAEA 368 from the International Atomic and Energy Agency (IAEA) were used to check the accu- racy of the results. Samples and background were counted for nominally $172800 \mathrm{~s}$ (corresponding to two days). ${ }^{210} \mathrm{~Pb}$ activity was determined by direct measurements of its gamma decay energy at 46.5 $\mathrm{keV}$. Activity concentrations of ${ }^{214} \mathrm{~Pb}$ and ${ }^{214} \mathrm{Bi}$ were quantified using the $351.9 \mathrm{keV}$ and $609.3 \mathrm{keV}$ photopeaks, respectively. ${ }^{137} \mathrm{Cs}$ (half life: 30.2 years) was measured by its emissions at $662 \mathrm{keV}$. Excess ${ }^{210} \mathrm{~Pb}\left({ }^{210} \mathrm{~Pb}\right.$ xs $)$ activity was calculated by subtracting the ${ }^{226} \mathrm{Ra}$ activity from the total ${ }^{210} \mathrm{~Pb}$.

\section{Sediment accumulation rate}

Sediment reworking due to physical or biological agents may affect the excess ${ }^{210} \mathrm{~Pb}$ distribution along the sediment. Goldberg and Koide (1962) pointed out that the main processes governing excess ${ }^{210} \mathrm{~Pb}$ profiles in the seabed are sediment accumulation rates, radioactive decay and particle mixing. They proposed a onedimensional advection-diffusion model to calculate the sedimentation rate $\left(\mathrm{S}\right.$, in $\left.\mathrm{cm} \mathrm{yr}^{-1}\right)$ and the mixing coefficient $\left(\mathrm{D}_{\mathrm{b}}\right.$; in $\left.\mathrm{cm}^{2} \mathrm{yr}^{-1}\right)$ that describes the intensity of particle reworking $\left(\mathrm{D}_{\mathrm{b}}\right.$, in $\left.\mathrm{cm}^{2} \mathrm{yr}^{-1}\right)$ :

$$
\frac{\partial A}{\partial t}=D_{b}\left(\frac{\partial^{2} A}{\partial x^{2}}\right)-S\left(\frac{\partial A}{\partial x}\right)-\lambda A
$$

where $\mathrm{A}$ is the excess ${ }^{210} \mathrm{~Pb}$ activity $\left(\mathrm{Bq} \mathrm{kg}^{-1}\right)$ at a depth $\mathrm{x}(\mathrm{cm}), \lambda$ is the ${ }^{210} \mathrm{~Pb}$ decay constant $\left(0.0311 \mathrm{yr}^{-1}\right)$, and $\mathrm{S}$ and $\mathrm{D}_{\mathrm{b}}$ are assumed to be constant. As $\mathrm{D}_{\mathrm{b}}$ and $\mathrm{S}$ cannot be determined independently, a solution for $\mathrm{D}_{\mathrm{b}}$ can be obtained if $\mathrm{S}$ is known or assumed to be negligible. When the latter is not the case or no evidence supporting this is available, $\mathrm{S}$ can be determined from the ${ }^{210} \mathrm{~Pb}$ profile of the non-mixed layer, where $\mathrm{D}_{\mathrm{B}}$ is assumed negligible. Assuming steady state conditions and no mixing, Equation (1) can be solved under the boundary conditions of $\mathrm{A}=\mathrm{A}_{0}(\mathrm{x}=0)$ and $\mathrm{A} \rightarrow 0(\mathrm{x} \rightarrow \infty)$ by means of the equation:

$$
A=A_{0} \exp \left(-\frac{\lambda}{S} x\right)
$$

This is usually done by least-squares fitting of the logarithm of excess ${ }^{210} \mathrm{~Pb}$ versus depth for the strata below the sediment mixed layer (SML). Then, the sedimentation rate calculated by using Equation (2) can be introduced as a constant in Equation (1) to determine $\mathrm{D}_{\mathrm{B}}$, also using least-square fitting for the SML:

$$
A=A_{0} e^{\left.\left(\frac{s-\sqrt{\left(S^{2}+4 \lambda D_{b}\right.}}{2 D_{b}}\right) x\right)}
$$

In this study, we consider the ${ }^{210} \mathrm{~Pb}$ profile of core BC4 from the outer Bay of Cádiz as a two-layer system with an upper mixed layer extending to a distance $\mathrm{L}$ below the water-sediment interface (SML) and a second layer below L where no mixing takes place (Fig. 5). 


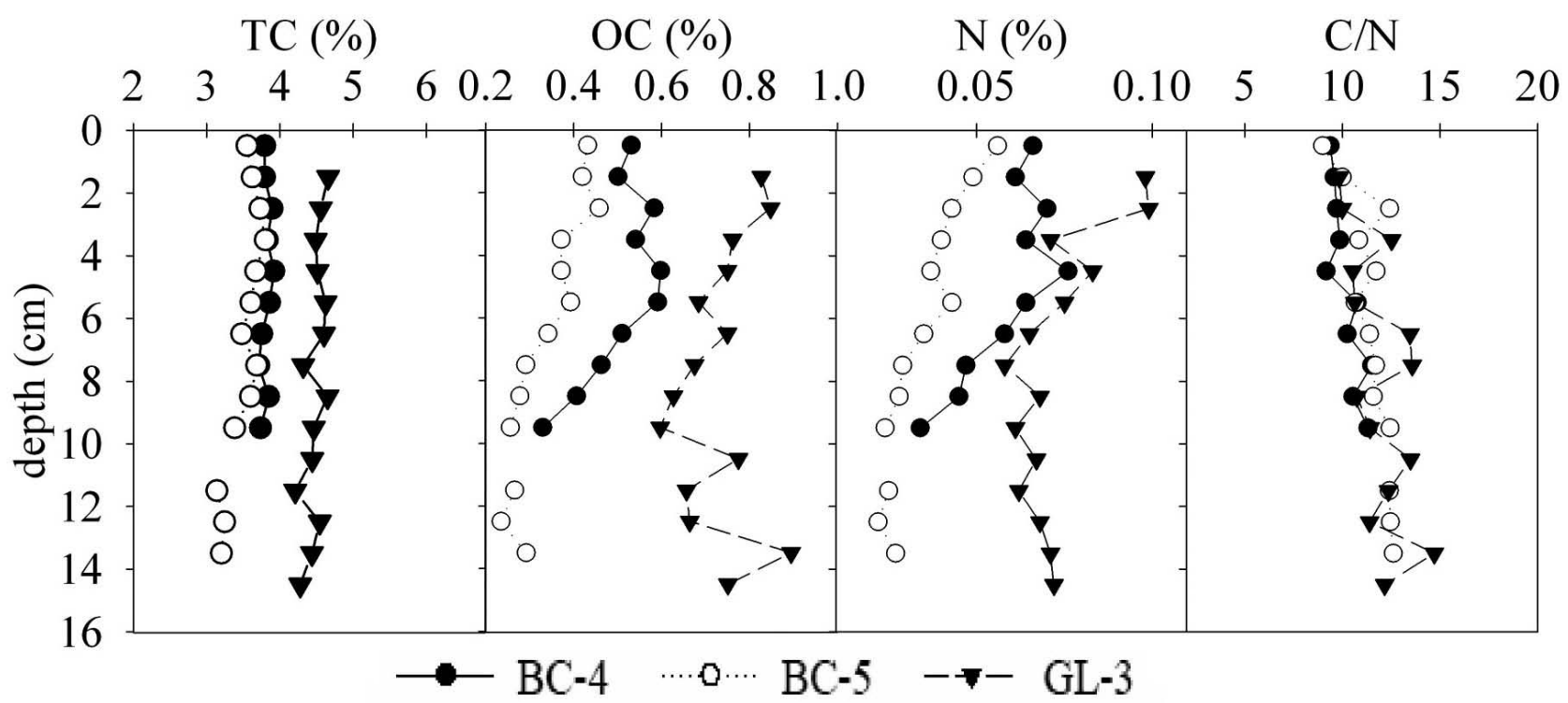

FIG. 2. - Depth profiles of TC, OC, TN, and OC:TN molar ratios of sediment cores from the Gulf of Cádiz. The origin of the cores is shown in Figure 1. Sediment cores BC4 and BC5 were obtained from the outer Bay of Cádiz, whereas core GL3 was obtained from the submarine prodelta of the River Guadalquivir.

\section{RESULTS}

\section{Total organic carbon (TOC) and total nitrogen (TN) distribution and ratios}

Data of TC (\%), TOC (\%), TN (\%), and TOC:TN ratios are displayed in Figure 2. The TOC content varied from 0.24 to $0.90 \mathrm{wt} \%$ (of total weight), with mean values of $0.51 \pm 0.09,0.34 \pm 0.07$ and 0.73 \pm 0.09 in cores from the outer Bay of Cádiz (BC4 and $\mathrm{BC5}$ ) and the Guadalquivir submarine prodelta (GL3), respectively; the TN content ranged from 0.02 to $0.10 \mathrm{wt} \%$, with mean values of $0.06 \pm 0.01,0.04$ \pm 0.01 and $0.07 \pm 0.01$ in cores BC4, BC5 and GL3, respectively; the TOC:TN ratio varied from 9.0 to 14.7, and mean values of $10.2 \pm 0.8,11.5 \pm 1.1$ and $11.9 \pm 1.5$ were found in cores $\mathrm{BC} 4, \mathrm{BC} 5$ and GL3, respectively.

\section{Sediment geochemistry}

The vertical profiles of major and minor elements ( $\mathrm{Si}, \mathrm{Ti}, \mathrm{Al}, \mathrm{Fe}, \mathrm{Mg}, \mathrm{Ca}, \mathrm{K}, \mathrm{Na}, \mathrm{P}, \mathrm{S}$ ) and selected trace elements (Mn, Sc, V, Cr, Ni, Cu, Zn, Rb, Sr, Y, Zr, $\mathrm{Ba}, \mathrm{Ce}, \mathrm{Pb}, \mathrm{Hg}$ ) are reported in Figures 3 and 4 respectively. The profiles of the three cores are reported in the same diagram to facilitate comparison and discussion of the most relevant features.

$\mathrm{CaO}$ concentrations (Fig. 3) are directly related to carbonate content, which can be calculated from TC data $\left(27.0-28.7 \mathrm{wt} \% \mathrm{CaCO}_{3}\right.$ in $\mathrm{BC} 4 ; 24.0-28.6 \mathrm{wt} \%$ $\mathrm{CaCO}_{3}$ in $\mathrm{BC} 5 ; 29.4-33.5 \mathrm{wt} \% \mathrm{CaCO}_{3}$ in GL3) that are consistent with the maps shown by López-Galindo et al. (1999). The profile of $\mathrm{CaO}$ is constant in $\mathrm{BC} 4$ (14.5$15.9 \mathrm{wt} \% \mathrm{CaO}$ ) but displays wider dispersion in $\mathrm{BC} 5$ (14.6-19.3 wt\% $\mathrm{CaO})$, with maxima between 1 and 3
TABLE 1. - Concentrations of metals measured in each core. Results for $\mathrm{V}, \mathrm{Cr}, \mathrm{Ni}, \mathrm{Cu}, \mathrm{Zn}$ and $\mathrm{Pb}$ are expressed in $\mu \mathrm{g} \cdot \mathrm{g}^{-1}$, whereas results for $\mathrm{Hg}$ are expressed in $\mathrm{ng} \cdot \mathrm{g}^{-1}$. Sediment cores BC4 and BC5 were obtained from the outer Bay of Cádiz, whereas core GL3 was obtained from the submarine prodelta of the River Guadalquivir.

\begin{tabular}{lccc}
\hline & BC4 & BC5 & GL3 \\
\hline $\mathrm{V}$ & 69 & 68 & 92 \\
$\mathrm{Cr}$ & 58 & 46 & 64 \\
$\mathrm{Ni}$ & 27 & 23 & 48 \\
$\mathrm{Cu}$ & 34 & 34 & 54 \\
$\mathrm{Zn}$ & 87 & 81 & 143 \\
$\mathrm{~Pb}$ & 38 & 33 & 64 \\
$\mathrm{Hg}$ & 168 & 148 & 335 \\
\hline
\end{tabular}

$\mathrm{cm}$ and minima between 11 and $13 \mathrm{~cm}$; on average core GL3 from the Guadalquivir submarine prodelta had a higher concentration and a lower dispersion (16.3-18.0 $\mathrm{wt} \% \mathrm{CaO}$ ).

Trace metals of environmental interest (Fig. 4 and Table 1) did not reach a high maximum concentration (Table 1) and displayed rather constant downcore profiles both in the outer Bay of Cádiz and in the Guadalquivir submarine prodelta area (Fig. 4), except for $\mathrm{Hg}$ in core $\mathrm{BC} 4$ and $\mathrm{BC} 5$, where an enrichment at the top was observed. The concentrations of trace metals in core GL3 were higher than those in the two cores of the Bay of Cádiz.

\section{${ }^{210} \mathrm{~Pb}$ and ${ }^{137} \mathrm{Cs}$ profiles and sediment accumulation rates}

Data of bulk density and excess ${ }^{210} \mathrm{~Pb}$ activity measured in the outer Bay of Cádiz (core BC4) are reported in Table 2; the ${ }^{210} \mathrm{~Pb}$ profile is shown in Figure 5 . The excess ${ }^{210} \mathrm{~Pb}$ activity varied from about $40-50$ $\mathrm{Bq} \mathrm{kg}^{-1}$ in the upper layers to $5 \mathrm{~Bq} \mathrm{~kg}^{-1}$ in the deeper layer. On the basis of the excess ${ }^{210} \mathrm{~Pb}$ activity profile, 
$\mathrm{SiO}_{2} \mathrm{wt} \% \quad \mathrm{TiO}_{2} \mathrm{wt} \% \quad \mathrm{Al}_{2} \mathrm{O}_{3} \mathrm{wt} \% \quad \mathrm{Fe}_{2} \mathrm{O}_{3} \mathrm{wt} \%$
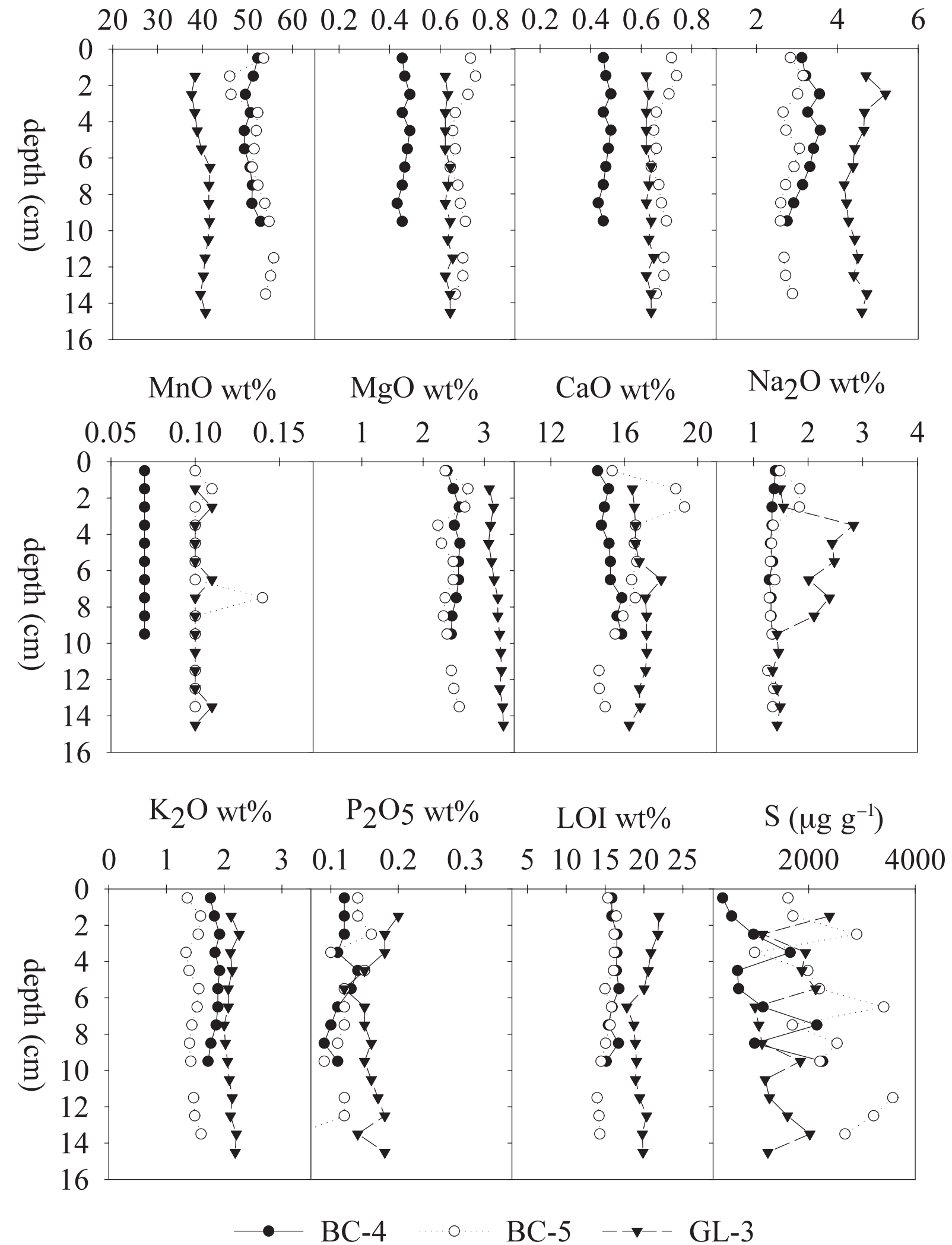

FIG. 3. - Depth profiles of major elements in the sediment cores from the Gulf of Cádiz. The origin of the cores is shown in Figure 1. Sediment cores BC4 and BC5 were obtained from the outer Bay of Cádiz, whereas core GL3 was obtained from the submarine prodelta of the River Guadalquivir. 

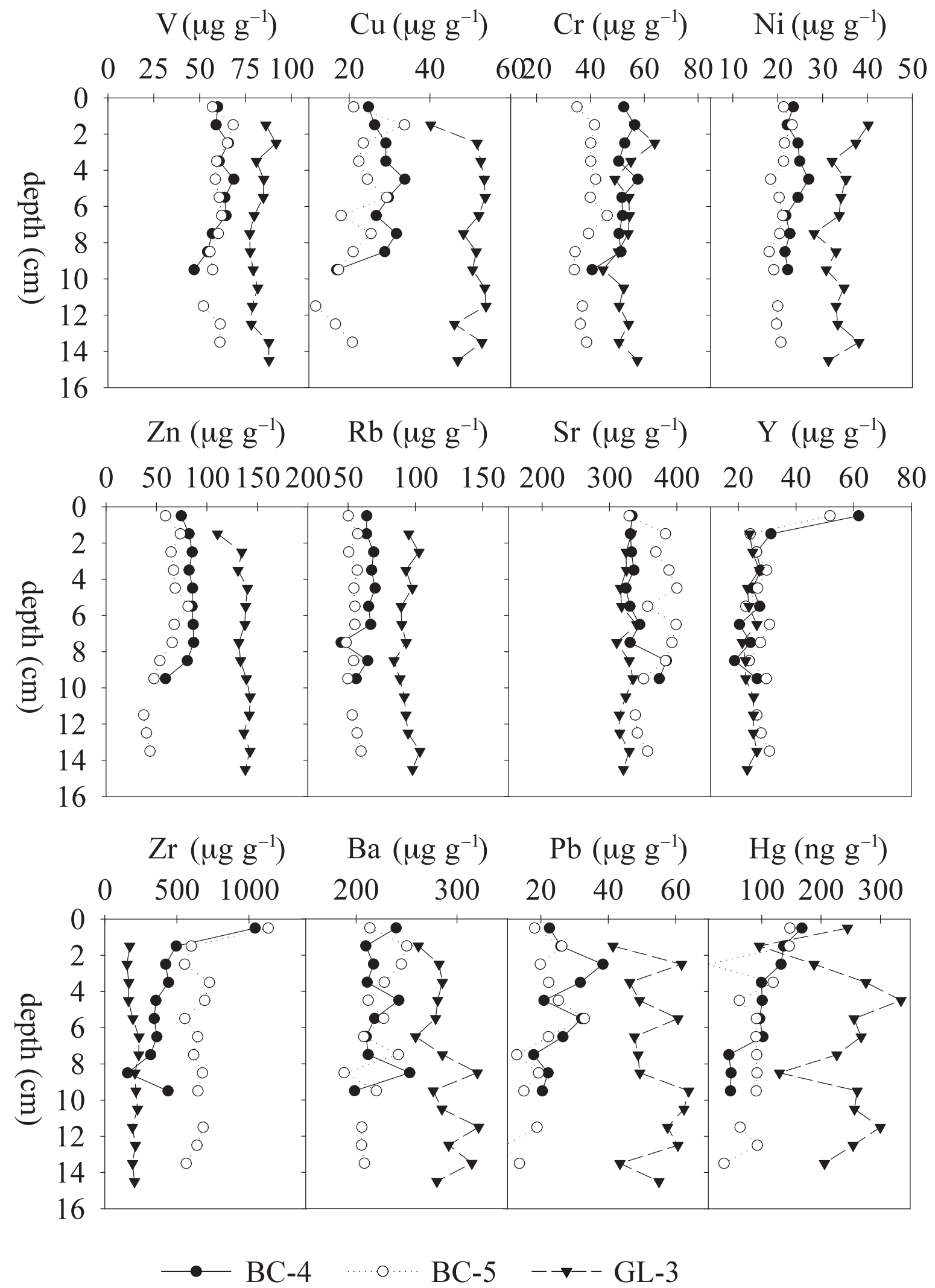

FIG. 4. - Depth profiles of trace elements in the sediment cores from the Gulf of Cádiz. The origin of the cores is shown in Figure 1. Sediment cores BC4 and BC5 were obtained from the outer Bay of Cádiz, whereas core GL3 was obtained from the submarine prodelta of the River Guadalquivir. 
TABLE 2. - Bulk density and ${ }^{210} \mathrm{~Pb}_{\mathrm{xs}}$ profiles in sediment core $\mathrm{BC} 4$ from the outer Bay of Cádiz.

\begin{tabular}{lcc}
\hline Section $(\mathrm{cm})$ & Bulk density $\left(\mathrm{g} \mathrm{cm}^{-3}\right)$ & ${ }^{210} \mathrm{~Pb}_{\mathrm{xs}}\left(\mathrm{Bq} \mathrm{kg}^{-1}\right)$ \\
\hline $0-1$ & 0.9 & $44 \pm 4$ \\
$1-2$ & 1.1 & $37 \pm 4$ \\
$2-3$ & 1.0 & $45 \pm 4$ \\
$3-4$ & 1.1 & $39 \pm 4$ \\
$4-5$ & 1.1 & $51 \pm 5$ \\
$5-6$ & 1.1 & $38 \pm 4$ \\
$6-7$ & 1.1 & $29 \pm 4$ \\
$7-8$ & 1.2 & $21 \pm 3$ \\
$8-9$ & 1.3 & $17 \pm 3$ \\
$9-10$ & 1.3 & $5 \pm 3$ \\
\hline
\end{tabular}

we considered the surface mixed layer (SML) to be the slice from 0 to $5 \mathrm{~cm}$ and the non-mixed layer to be the slice from 5 to $10 \mathrm{~cm}$. When applying Equation 2 to the non-mixed layer of core $\mathrm{BC} 4$, a sedimentation rate $S$ of $0.10 \pm 0.01 \mathrm{~cm} \mathrm{yr}^{-1}(r=0.9847, p=0.0007)$ and an apparent sediment accumulation rate (SAR) of $0.11 \pm 0.01 \mathrm{~g} \mathrm{~cm}^{-2} \mathrm{yr}^{-1}(\mathrm{r}=0.9867, \mathrm{p}=0.0005)$ were obtained. The ${ }^{210} \mathrm{~Pb}$ mixing-coefficient $\left(\mathrm{D}_{\mathrm{b}}\right)$ calculated with Equation 3 was $1.07 \pm 0.13 \mathrm{~cm}^{2} \mathrm{yr}^{-1}(\mathrm{r}=$ $0.77, \mathrm{p}=0.00003)$.

${ }^{137} \mathrm{Cs}$ vertical profile remained quite constant in the upper layers $\left(2-3 \mathrm{~Bq} \mathrm{~kg}^{-1}\right)$, declining downward to about $1 \mathrm{~Bq} \mathrm{~kg}^{-1}$, with no evidence of fallout peaks (Fig. 5).

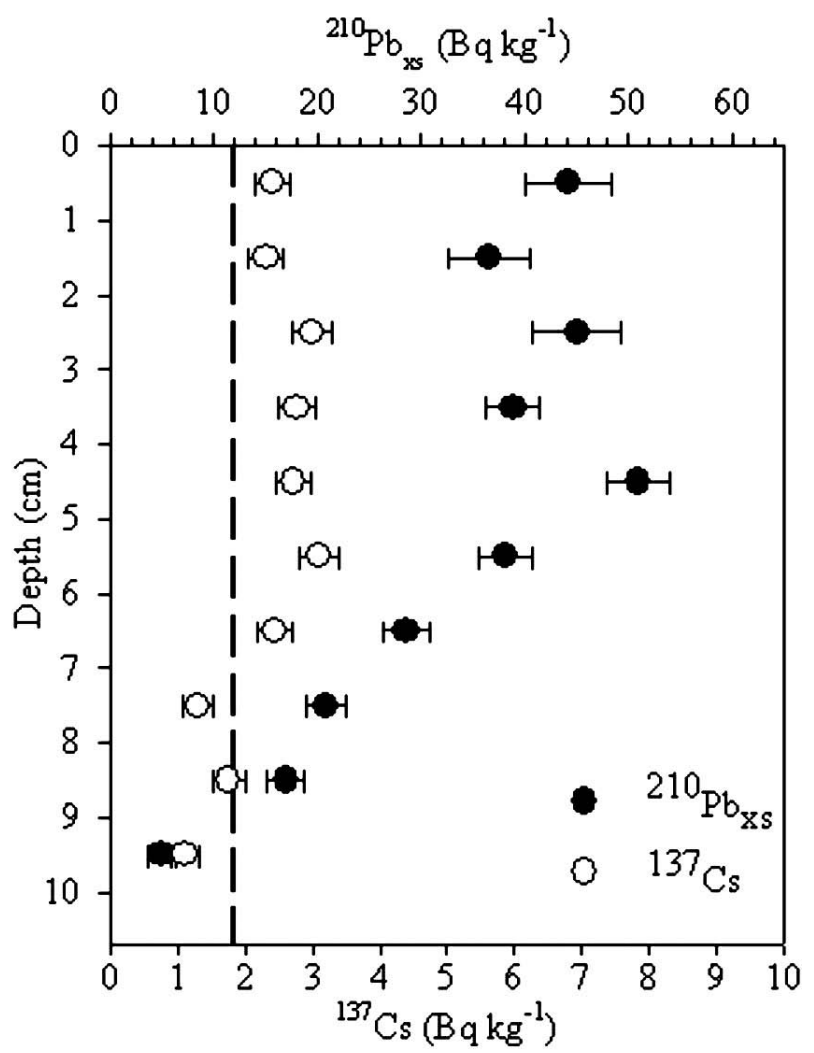

FIG. 5. $-{ }^{210} \mathrm{~Pb}$ (filled circles) and ${ }^{137} \mathrm{Cs}$ (open circles) activities in core $\mathrm{BC} 4$ from the outer Bay of Cádiz. Dashed line indicates average supported ${ }^{210} \mathrm{~Pb}\left(={ }^{226} \mathrm{Ra}\right)$.

\section{DISCUSSION}

\section{Total organic carbon (TOC) and total nitrogen (TN) distribution and ratios}

TOC values found in the sediments under the influence of the River Guadalquivir (core GL3) and those from the Bay of Cádiz (core BC4 and BC5) fall within the typical low range for coastal sediments (Dickens et $a l ., 2004$ ), and are close to those reported for marine sediments from the inner continental shelf of the southwest Atlantic coast of Spain (López-Capel et al., 2006; Sánchez-García et al., 2008).

The most diagnostic point is the $\mathrm{C} / \mathrm{N}$ index (atomic TOC/TN ratio), which can be used to distinguish among potential organic matter origins (e.g. marine phytoplankton $\mathrm{C} / \mathrm{N}=7.4 \pm 1.3$, and cellulose rich vascular land plants $\mathrm{C} / \mathrm{N} \geq 20$; Meyers, 1994, 1997; Anderson and Sarmiento, 1994). Thus, the $\mathrm{C} / \mathrm{N}$ values found here (Fig. 2), mostly around 10 with the exception of few layers in core GL3, seem to be attributable to a predominantly marine origin for the sedimentary organic matter (OM). However, one should be cautious with such an interpretation, since the observed $\delta^{15} \mathrm{~N}$ values in the top $20 \mathrm{~cm}$ from the Gulf of Cádiz (2.9-6.1\%o, Sánchez-García et al., 2008) are likely to indicate a mixed contribution of both marine and terrestrial organic matter.

\section{Sediment geochemistry}

Core GL3 from the area under the influence of the River Guadalquivir has a completely different composition to that of the other two cores. It has higher concentrations of $\mathrm{Al}_{2} \mathrm{O}_{3}$ and other elements such as $\mathrm{Fe}_{2} \mathrm{O}_{3}$, $\mathrm{MgO}, \mathrm{K}_{2} \mathrm{O}, \mathrm{V}, \mathrm{Ni}, \mathrm{Cu}, \mathrm{Zn}, \mathrm{Rb}, \mathrm{Pb}$ (Figs. 3 and 4) that can be related to a clay mineral fraction, which is dominant in the sediments of this area (López-Galindo et al., 1999). The profiles of these elements in core GL3 are rather regular, with a minimum in concentration for almost all elements at $7 \mathrm{~cm}$ depth within the core. These elements have lower concentrations and generally comparable downcore profiles in the two cores $(\mathrm{BC} 4$ and BC5) from the outer Bay of Cádiz (Figs. 3 and 4). Some difference is evident for $\mathrm{K}_{2} \mathrm{O}$, and in general, core $\mathrm{BC} 5$ displays a greater variation in the topmost 5 $\mathrm{cm}$, with an increase between 2 and 3 centimetre followed by a more or less regular trend.

$\mathrm{SiO}_{2}$ concentrations are high in cores from the outer Bay of Cádiz, and display profiles that are generally opposite to the clay mineral fraction described above (Fig. 3). The $\mathrm{SiO}_{2} / \mathrm{Al}_{2} \mathrm{O}_{3}$ ratio shows a strong positive correlation with grain-size in several cases (ViscosiShirley et al., 2003; Dinelli et al., 2007) and in the cores of the Bay of Cádiz the values are typical of a sandy sediment (5.5-7.2 $\mathrm{SiO}_{2} / \mathrm{Al}_{2} \mathrm{O}_{3}$ in $\mathrm{BC} 4$, 5.5-8.4 $\mathrm{SiO}_{2} / \mathrm{Al}_{2} \mathrm{O}_{3}$ in $\mathrm{BC} 5$ ), whereas in core GL3 the lower values (3.4-4.2) point to a consistently finer mean grain-size, in accordance with the grain-size data pub- 
lished by López-Galindo et al. (1999) and GutiérrezMas et al. (2003). The significant enrichment of $Y$ and $\mathrm{Zr}$ in both cores from the outer Bay of Cádiz can be related to sorting effects on trace minerals (e.g. zircon) (Fig. 4). A similar effect is common in sedimentary environments (Fralick and Kronberg, 1997; Dypvik and Harris, 2001; García et al., 2004), and is related to the action of bottom currents that selectively remove the fine grain size fraction and concentrate the heavy minerals. In general, trace metals do not reach very high concentrations, except $\mathrm{Pb}$ in core GL3, which reaches maximum concentrations of $65 \mu \mathrm{g} \mathrm{kg}^{-1}$ (Fig. 4), three times the average shale composition $\left(20 \mu \mathrm{g} \mathrm{kg}^{-1}\right.$, Turekian and Wedephol, 1961). However, this result is consistent with data reported for the Guadalquivir estuary (Riba et al., 2004).

The vertical profiles of the trace metals do not indicate surface enrichment in sediments from the outer Bay of Cádiz; however, a slight increase in $\mathrm{Cr}, \mathrm{Cu}, \mathrm{Zn}$ and $\mathrm{Pb}$ concentrations in core $\mathrm{BC} 5$ can be observed in the topmost $8 \mathrm{~cm}$ (Fig. 4), and the same feature can also be observed in $\mathrm{BC} 4$, though only one sample shows reduced values at the bottom of the core. No significant downcore changes can be observed in core GL3.

Cores collected in the outer Bay of Cádiz show similar mercury profiles (Fig. 4), with higher concentrations at the top decreasing to nearly constant levels with depth. Mercury levels found in the upper sections (133-168 $\mathrm{ng} \mathrm{g}^{-1}$ and 119-148 $\mathrm{ng} \mathrm{g}^{-1}$, respectively) are consistently lower than those found in the inner Bay and littoral ecosystems in the Gulf of Cádiz (DelValls et al., 2002; Ligero et al., 2002). The lowest levels were found in deeper layers of cores BC4 and BC5 (45-49 $\mathrm{ng} \mathrm{g}^{-1}$ and 37-64 $\mathrm{ng} \mathrm{g}^{-1}$, respectively), showing values comparable to those detected in mud volcano cores collected from the Gulf of Cádiz (Mieiro et al., 2007). Mercury concentrations of about $50 \mathrm{ng} \mathrm{g}^{-1}$ were also observed at the base of 2-m cores collected in the Gulf of Cádiz, and resulted from transport by the Rivers Tinto and Odiel (Cossa et al., 2001). Conversely, core GL3 from the Guadalquivir area exhibited the highest concentrations, with mercury peaks observed at different depths (Fig. 4). These results are consistent with the fact that this core was collected in an area located in the submarine prodelta of the River Guadalquivir, which is the main fluvial input of the Gulf of Cádiz. Hg levels found in this core fall within the range detected in sediments from the River Guadiamar, a tributary of the River Guadalquivir, and in littoral sediments under the influence of the Odiel system (Alastuey et al., 1999; Usero et al., 2005; Sáinz and Ruiz, 2006).

\section{${ }^{210} \mathrm{~Pb}$ and ${ }^{137} \mathrm{Cs}$ profiles and sediment accumulation rate}

The magnitude of calculated sedimentation rate and sediment accumulation rate (SAR) in the outer Bay of Cádiz broadly reflects values that have also been found in shelves of the mid-Atlantic, the western Mediterranean, and the North Iberian Margin (Sánchez-Cabeza et al., 1999; Masqué et al., 2003; Sommerfield, 2006; Jouanneau et al., 2008). Bioturbation rates closely resemble mixing in deep-sea sediments rather than the much more rapid mixing seen in shallow-water environments (Schmidt et al., 2002; Masqué et al., 2003; Schmidt et al., 2007). The effects of mixing are therefore reasonably low for the Cádiz shelf environment, but should be considered for high resolution or precise geochronological studies.

${ }^{137} \mathrm{Cs}$ activities detected were well below $10 \mathrm{~Bq}$ $\mathrm{kg}^{-1}$ (Fig. 5), in agreement with the findings of Ligero et al. $(2002 ; 2005)$, but the ${ }^{137} \mathrm{Cs}$ inventory $(26 \mathrm{mBq}$ $\mathrm{cm}^{-2}$ ) was lower than the average inventory found in the inner Bay of Cádiz (Ligero et al., 2005). A strong positive correlation between ${ }^{137} \mathrm{Cs}$ and organic carbon was found $\left(r^{2}=0.84, p=0.0002\right)$, suggesting that the capacity of retention of ${ }^{137} \mathrm{Cs}$ in the sediment is linked to the organic matter (Rubio et al., 2003). However, mobility of ${ }^{137} \mathrm{Cs}$ in the sediment column through processes of molecular diffusion and biological activity cannot be excluded in this area, considering that BC sites showed slightly higher faunal density and biomass than GL sites, as well as greater species richness according to the findings of Ferrón et al. (2009).

The core (BC4) does not show maximum values that can be directly associated with the historical fallout of ${ }^{137} \mathrm{Cs}$, in agreement with other studies carried out in Spanish coastal and marine ecosystems (Gascó et al., 1999; Rubio et al., 2003; Ligero et al., 2005). The impact of the Chernobyl disaster has not been great in Spain, as can be inferred from the data reported by UNSCEAR (1988) and De Cort et al. (1998). Average deposition densities for ${ }^{137} \mathrm{Cs}$ after the Chernobyl disaster were about $0.02 \mathrm{kBq} \mathrm{m}^{-2}$ in the western Spanish regions, and about $0.07 \mathrm{kBq} \mathrm{m}^{-2}$ in the eastern regions. Finally, despite the close proximity, the Gulf of Cádiz was probably not contaminated by fallout from the accident in Algeciras in 1998; this conclusion agrees with plume trajectory simulations carried out by Vogt et al. (1998) and Quelo et al. (2007).

\section{CONCLUSIONS}

Sediment cores from the outer Bay of Cádiz display a similar composition, reflecting a relatively coarse grained texture, whereas sediments in the Guadalquivir prodelta area are dominated by finer grain sizes, as suggested from bulk geochemical analyses. Levels of trace metals $(\mathrm{V}, \mathrm{Ni}, \mathrm{Cu}, \mathrm{Zn}, \mathrm{Pb}$ and $\mathrm{Hg}$ ) are higher in the Guadalquivir prodelta area than in the Bay of Cádiz area and are influenced by the contribution of the heavily contaminated sediments from the River Guadalquivir. In this area, trace metals do not vary with depth, whereas a shift in concentration is observed in the Bay of Cádiz cores. Future studies are needed to extend the application of the ${ }^{210} \mathrm{~Pb}$ mixing model for estimating bioturbation and sediment accumulation rates to other locations in the Bay of Cádiz and to the Gualdalquivir area, where no previous data are available. 


\section{AKNOWLEDGEMENTS}

This research was supported by the Spanish InterMinisterial Science and Technology Commission by means of the "EMIGAS" project (CTM2005-01364/ MAR).

\section{REFERENCES}

Alastuey, A., A. García-Sánchez, F. López and X. Querol. - 1999. Evolution of pyrite mud weathering and mobility of heavy metals in the Guadiamar valley after the Aznalcóllar spill, southwest Spain. Sci. Tot. Environ., 242: 41-55.

Anderson, L.A. and J.L. Sarmiento. - 1994. Redfield ratios of remineralization determined by nutrient data analysis. Global Biogeochem. Cy., 8: 65-80.

Berelson, W.M., J. McManus, K.H. Coale, K.S. Johnson, D. Burdige, T. Kilgore, D. Colodner, F. Chavez, R. Kudela and J. Boucher. - 2003. A time series of benthic flux measurements from Monterey Bay, CA. Cont. Shelf. Res., 23: 457-481.

Carranza-Edwards, A., L. Rosales-Hoz, J. Urrutia-Fucugauchi, A. Sandoval-Fortanel, E. Morales de la Garza and R. Lozano Santa Cruz. - 2005. Geochemical distribution pattern of sediments in an active continental shelf in Southern Mexico. Cont. Shelf Res., 25: 521-537.

Cossa, D., F. Elbaz-Poulichet and J.M. Nieto. - 2001. Mercury in the Tinto-Odiel estuarine system (of Cádiz, Spain): sources and dispersion. Aquat. Geochem., 7: 1-12.

De Cort, M., G. Dubois, S.D. Fridman, M.G. Germenchuk, Y.A Izrael, A. Janssens, A.R. Jones, G.N. Kelly, E.V. Kvasnikova, I.I. Matveenko, I.M. Nazarov, Yu.M. Pokumeiko, V.A. Sitak, E.D. Stukin, L.Ya. Tabachny, Yu.S. Tsaturov and S.I. Avdyushin. - 1998. Atlas of Caesium Deposition on Europe after the Chernobyl Accident. EUR Report 16733, EC, Office for Official Publications of the European Commission Communities, Luxembourg.

DelValls, T.A., J.M. Forja and A. Gómez-Parra. - 2002. Seasonality of contamination, toxicity, and quality values in sediments from littoral ecosystems in the Gulf of Cádiz (SW Spain). Chemosphere, 46: 1033-1043.

Dickens, A.F., Y. Gélinas, C.A. Masiello, S. Wakeham and J.I. Hedges. - 2004. Reburial of fossil organic carbon in marine sediments. Nature, 427: 336-338.

Dinelli, E., F. Tateo and V. Summa. - 2007. Geochemical and mineralogical proxies for grain size in mudstones and siltstones from the Pleistocene and Holocene of the Po River alluvial plain, Italy. In: J. Arribas, S. Critelli and M.J. Johnsson (eds.), Sedimentary Provenance and Petrogenesis: Perspectives from Petrography and Geochemistry. Geological Society of America Special Paper, 420: 25-36.

Dypvik, H. and N.B. Harris. - 2001. Geochemical facies analysis of fine-grained siliciclastics using $\mathrm{Th} / \mathrm{U}, \mathrm{Zr} / \mathrm{Rb}$ and $(\mathrm{Zr}+\mathrm{Rb}) / \mathrm{Sr}$ ratios. Chem. Geol., 181: 131-146.

Fabbri, D., C. Locatelli, C.E. Snape and S. Tarabusi. - 2001. Sulfur speciation in mercury-contaminated sediments of a coastal lagoon: the role of elemental sulphur. J. Environ. Monit., 3: 483-486.

Ferrón, S., F. Alonso-Pérez, E. Anfuso, F. J. Murillo, T. Ortega, C.G. Castro and J.M. Forja. - 2009. Benthic nutrient recycling on the northeastern shelf of the Gulf of Cádiz (SW Iberian Peninsula). Mar. Ecol. Prog. Ser., 390: 79-95.

Fralick, P.W. and B.I. Kronberg. - 1997. Geochemical discrimination of clastic sedimentary rock sources. Sediment. Geol., 113(1): 111-124.

Franzini, M, L. Leoni and M. Saitta. - 1972. A simple method to evaluate the matrix effects in X-Ray fluorescence analysis. $X$ Ray Spectrom., 1: 151-4.

García, D., C. Ravenne, B. Maréchal and J. Moutte. - 2004. Geochemical variability induced by entrainment sorting: Quantified signals for provenance analysis. Sediment. Geol., 171: 113-128.

Gascó, C., M.P. Antón, J. Meral and A.M. González. - 1999. Participación técnica del CIEMAT en estudios de radioecología en ecosistemas marinos europeos. ENRESA. Technical report $07 / 99$.
Goldberg, E.D. and M. Koide. - 1962. Geochronological studies of depp sea sediments by ionium/thorium method. Geochim. Cosmochim. Acta, 26: 417-450.

Gutiérrez-Mas, J.M., J.P. Moral, A. Sánchez, S. Domínguez and J.J. Muñoz-Pérez. - 2003. Multicycle sediments on the continental shelf of Cádiz (SW Spain). Estuar. Coast. Shelf Sci., 57: 667-677.

Hedges, J.I. and J.H. Stern. - 1984. Carbon and nitrogen determinations of carbonate-containing solids. Limnol. Oceanogr., 29: 667-663.

Jouanneau, J.-M., O. Weber, N. Champilou, P. Cirac, I. Muxika, A. Borja, A. Pascual, J. Rodríguez-Lázaro and O. Donard. - 2008. Recent sedimentary study of the shelf of the Basque country. $J$. Mar. Syst., 72: 397-406.

Leoni, L, M. Menichini and M. Saitta. - 1982. Determination of $\mathrm{S} \mathrm{Cl}$ and $\mathrm{F}$ in silicate rocks by $\mathrm{X}$-Ray fluorescence analyses. $X$-Ray Spectrom., 11: 156-8.

Ligero, R.A., M. Barrera, M. Casas-Ruiz, D. Sales and F., LópezAguayo. - 2002. Dating of marine sediments and time evolution of heavy metal concentrations in the Bay of Cádiz, Spain. Environ. Pollut., 118: 97-108.

Ligero, R.A., M. Barrera and M. Casas-Ruiza. - 2005. Levels of ${ }^{137} \mathrm{Cs}$ in muddy sediments of the seabed of the Bay of Cádiz, Spain. Part I. Vertical and spatial distribution of activities. $J$. Environ. Radioactiv., 80: 75-86.

Lobo, F.J., R. Sánchez, R. González, J.M.A. Dias, F.J. HernándezMolina, L.M. Fernández-Salas, V. Díaz del Río and I. Mendes. - 2004. Contrasting styles of the Holocene highstand sedimentation and sediment dispersal systems in the northern shelf of the Gulf of Cádiz. Cont. Shelf Res., 24: 461-482.

López-Capel, E., J.M. de la Rosa-Arranz, F.J. González-Vila, J.A. González-Pérez and D.A.C. Manning. - 2006. Elucidation of different forms of organic carbon in marine sediments from the Atlantic coast of Spain using thermal analysis coupled to isotope ratio and quadrupole mass spectrometry. Org. Geochem., 37: 1983-1994.

López-Galindo, A, J. Rodero and A. Maldonado. - 1999. Surface facies and sediment dispersal patterns: southeastern Gulf of Cádiz, Spanish continental margin. Mar. Geol., 155: 83-98.

Mackenzie, F.T., A. Andersson, A. Lerman and L.M. Ver - 2005. Boundary exchanges in the global coastal margin: implications for the organic and inorganic carbon cycles. In: A.R. Robinson and K.H. Brink (eds.), The Sea (8), pp. 193-225. Harvard University Press, Cambridge.

Masqué, P., J. Fabres, M. Canals, J.A. Sanchez-Cabeza, A. SanchezVidal, I. Cacho, A.M. Calafat and J.M. Bruach. - 2003. Accumulation rates of major constituents of hemipelagic sediments in the deep Alboran Sea: a centennial perspective of sedimentary dynamics. Mar. Geol., 193: 207-233.

Meyers, P.A. - 1994. Preservation of elemental and isotopic source identification of sedimentary organic matter. Chem. Geol., 114(3-4): 289-302.

Meyers, P.A. - 1997. Organic geochemical proxies of paleoceanographic, paleolimnologic, and paleoclimatic processes. Org. Geochem., 27(5-6): 213-250.

Mieiro, C.L., P. Pato, E. Pereira, F. Mirante, J.A.P. Coutinho, L.M. Pinheiro, V.H. Magalhães and A.C. Duarte. - 2007. Total mercury in sediments from mud volcanoes in Gulf of Cádiz. Mar. Pollut. Bull., 54: 1523-1558.

Palinkas, C.M. and C.A. Nittrouer. - 2007. Modern sediment accumulation on the Po shelf, Adriatic Sea. Cont. Shelf Res., 27: 489-505.

Quelo, D., M. Krysta, M. Bocquet, O. Isnard, Y. Minier and B. Sportisse - 2007. Validation of the POLYPHEMUS platform on the ETEX, Chernobyl and Algeciras cases. Atmos. Environ., 41: $5300-5315$

Riba, I., M. Conradi, J.M. Forja and T.A. DelValls. - 2004. Sediment quality in the Guadalquivir estuary: lethal effects associated with the Aznalcollar mining spill. Mar. Pollut. Bull., 48: $144-152$.

Rubio, L., A. Linares-Rueda, C. Dueñas, M.C. Fernández, V. Clavero, F.X. Niell and J.A. Fernández. - 2003. Sediment accumulation rate and radiological characterisation of the sediment of Palmones River estuary (southern of Spain). J. Environ. Radioactiv., 65: 267-280.

Sáinz, A. and F. Ruiz. - 2006. Influence of the very polluted inputs of the Tinto-Odiel system on the adjacent littoral sediments of 
southwestern spain: A statistical approach. Chemosphere, 62: 1612-1622.

Sánchez-Cabeza, J.A., P. Masqué, I. Ani-Ragolta, J. Merino, M. Frignani, F. Alvisi, A. Palanques and P. Puig. - 1999. Sediment accumulation rates in the southern Barcelona continental margin (NW Mediterranean Sea) derived from ${ }^{210} \mathrm{~Pb}$ and ${ }^{137} \mathrm{Cs}$ chronology. Prog. Oceanogr., 44: 313-332.

Sánchez-García, L., J.R. de Andrés, J.A. Martín-Rubía, F. J. González-Vila and O.Polvillo. - 2008. Use of lipid biomarker patterns as a proxy of environmental variability in the coastal sedimentary record from the Gulf of Cádiz (SW Spain). Org. Geochem., 39: 958-964.

Schmidt, S., Tj.C.E. van Weering, J.L. Reyss and P. van Beek. 2002. Seasonal deposition and reworking at the sediment-water interface on the northwestern Iberian margin. Progr. Oceanogr., 52: 331-348.

Schmidt S., J.M. Jouanneau, O. Weber, P. Lecroart, O. Radakovitch, F. Gilbert and D. Jézéquel. - 2007. Sedimentary processes in the Thau Lagoon (France): From seasonal to century time scales. Estuar. Coast. Shelf Sci., 72: 534-542.

Sommerfield, C.K. - 2006. On sediment accumulation rates and stratigraphic completeness: Lessons from Holocene ocean margins. Cont. Shelf Res., 26: 2225-2240.

Spagnoli, F., G. Bartholini, E. Dinelli and P. Giordano. - 2008. Geochemistry and particle size of surface sediments of Gulf of Manfredonia (Southern Adriatic sea). Estuar. Coast. Shelf Sci., 80: $21-30$.
Turekian, K.K., K.H. Wedephol. - 1961. Distribution of the elements in some major units of the Earth's crust. Geol. Soc. Am. Bull., 72: 175-192.

UNSCEAR. - 1988. Sources, effects and risks of ionizing radiation. Appendix to Annex G, 'Early effects in man of high doses of radiation'. United Nations Scientific Committee on the Effects of Atomic Radiation. Report to the General Assembly with annexes. United Nations, New York, USA.

Usero, J., J. Morillo and I. Gracia. - 2005. Heavy metal concentrations in molluscs from the Atlantic coast of southern Spain. Chemosphere, 59: 1175-1181.

Van Geen, A., J.F. Adkins, E.A. Boyle, C.H. Nelson and A. Palanques. - 1997. A $120 \mathrm{yr}$ record of widespread contamination from mining of the Iberian pyrite belt. Geology, 25: 291-294.

Viscosi-Shirley C., K. Mammone, N. Pisias and J. Dymond. 2003. Clay mineralogy and multi element chemistry of surface sediments on the Siberian- Arctic shelf: Implications for sediment provenance and grain size sorting. Cont. Shelf Res., 23: $1175-1200$.

Vogt, P.J., B.M. Pobanz, F.J. Aluzzi, R.L. Basket and T.J. Sullivan. - 1998. ARAC simulation of the Algeciras (Spain) steel mill Cs-137 release. Technical Report JC-131330 ARAC, Lawrence Livermore National Laboratory, California, USA.

Received November 1, 2008. Accepted July 30, 2010. Published online November 13, 2010. 